\title{
Effects of phentolamine on coronary blood flow in patients with recent myocardial infarction
}

\author{
Lawrence Gould, C. V. R. Reddy, Charles J. Blatt, Robert F. Gomprecht, and David B. Hayt \\ With the technical assistance of Luis Lopez, James Gelsomino, Luis Rivas, and Ben Texeria \\ From the Cardiac Catheterization Laboratory, Misericordia Hospital, N.Y., U.S.A.
}

The myocardial clearance of rubidium may be obtained by praecordial counting after intravenous injection of $R b^{86} \mathrm{Cl}$. Eight patients with recent myocardial infarction had this determination performed before and after the infusion of $10 \mathrm{mg}$ phentolamine at a rate of $0.3 \mathrm{mg} /$ minute. The average predrug myocardial clearance of $R b$ was $89.3 \pm 29.9 \mathrm{ml} / \mathrm{min}$ per $100 \mathrm{~g}$ myocardium. After phentolamine, the average myocardial clearance rose to $117.3 \pm 33.3 \mathrm{ml} / \mathrm{min}$ per $100 \mathrm{~g}$ myocardium $(P<0.01)$. An explanation for this finding is presented as well as its possible clinical applications.

The systemic arterial pressure is frequently raised during the course of a myocardial infarction. A reduction of the raised blood pressure should decrease the myocardial oxygen consumption requirements, and might limit the extent of the infarct and improve cardiac performance (Maroko et al., I97I). Based on these concepts, phentolamine has been administered to patients with an acute myocardial infarct (Kelly et al., 1973). A reduction of the raised systemic arterial pressure has led to a fall in the ventricular end-diastolic pressure and a rise in the cardiac output.

The reduction in the myocardial oxygen requirements may improve flow to the ischaemic area of the endocardium by favourably altering intramyocardial pressure, and hence the distribution of blood flow across the myocardium (Fortuin et al., 197I). In order to answer this unresolved question, the effect of phentolamine on the coronary blood flow in patients with a recent myocardial infarction has been studied.

\section{Methods}

The praecordial counting was performed with a $5 \times 5 \mathrm{~cm}$ $\mathrm{NaI}(\mathrm{Tr})$ scintillation detector with a lead collimator, I $50 \mathrm{~mm}$ long with an external diameter I Io $\mathrm{mm}$. Pulses from the detector were fed via a pulse height analyser to a digital ratemeter and then to a recorder. For ${ }^{131}$ I activity the pulse height analyser was set for the 364 $\mathrm{KeV}$ photopeak with a $100 \mathrm{KeV}$ window. For ${ }^{86} \mathrm{Rb}$, the pulse height analyser was set for $1.08 \mathrm{MeV}$ with a 100 $\mathrm{KeV}$ window. The ratemeter time constant was set at 4 seconds for recording background and at 4 seconds during the procedures. The chart speed was set at $3 \mathrm{~cm}$ Received 9 October 1974. per minute. Blood activity was measured in a $5 \mathrm{~cm}$ welltype scintillation detector with the pulse height analyser setting as described for external counting of ${ }^{131} \mathrm{I}$ and ${ }^{86} \mathrm{Rb}$.

The counts are corrected for the relative inefficiencies in the in vivo and in vitro systems, introducing a coefficient $\overline{\mathbf{n}}$ calculated from the counting rates obtained when two 500-ml flasks containing known concentrations of ${ }^{131} \mathrm{I}$ and ${ }^{86} \mathrm{Rb}$ are counted externally under a standard geometrical arrangement.

$$
\overline{\mathrm{n}}=\frac{(\mathrm{c} . \mathrm{p} . \mathrm{m} \cdot / \mathrm{ml}){ }^{131} \mathrm{I}(\text { well }) \times \text { c.p.m. }{ }^{86} \mathrm{Rb}(\text { flask })}{(\text { c.p.m. } / \mathrm{ml}){ }^{86} \mathrm{Rb}(\text { well }) \times \text { c.p.m. }{ }^{131} \mathrm{I}(\text { flask })}
$$

\section{Experimental procedure}

The experiments were performed in the morning on resting subjects in the supine position. A Cournand cannula was introduced into the right brachial artery. The detector was positioned over the centre of the heart silhouette.

I $5 \mu \mathrm{Ci}^{131} \mathrm{I}$ as RIHSA, in 0.5 to $\mathrm{I} \mathrm{ml}$ saline, was then rapidly injected into the left cubital vein. Thirty seconds after the injection the praecordial counting and arterial blood sampling were started; both counting and blood sampling lasted 3 minutes and the rate of withdrawal was $\mathrm{I} \mathrm{ml}$ every 4 seconds.

Within 5 minutes, $150 \mu \mathrm{Ci}{ }^{86} \mathrm{Rb}$ as rubidium chloride in 0.5 to $\mathrm{I} \mathrm{ml} \mathrm{saline} \mathrm{was} \mathrm{rapidly} \mathrm{injected} \mathrm{into} \mathrm{a} \mathrm{cubital}$ vein. Praecordial counts and arterial blood were taken as after the RIHSA injection. Recording was continued until blood sampling and praecordial counting were completed.

Ten milligrams of phentolamine was then infused at a rate of $0.3 \mathrm{mg} / \mathrm{min}$. At the conclusion of the infusion, the radioisotope studies, using ${ }^{131} I$ and ${ }^{86} R b$, were repeated as described above. Care was taken to maintain the detector in the same position. 
All the blood samples were haemolysed and counted in duplicate. The $\overline{\mathbf{n}}$ coefficient was periodically measured to check the constancy of the conditions of the counting apparatus.

The blood pressure and cardiac rate were obtained before and after the phentolamine infusion.

\section{Calculations}

The myocardial clearance (MCR for ${ }^{86} \mathrm{Rb}$ ) was calculated in two steps:

(I) Calculation of the fraction $F$ of the praecordial counting rate caused by myocardial activity:

$$
F=\frac{{ }^{\mathrm{R}} \mathrm{Rb}-\overline{\mathrm{n}} \mathrm{W}_{\mathrm{B}} \overline{\mathrm{a}} \mathbf{R b}}{{ }^{\mathrm{R}} \mathrm{Rb}}
$$

where:

$$
\mathrm{W}_{B}=\frac{{ }^{\mathrm{R}} \mathrm{RIHSA}}{\overline{\mathrm{a}} \mathrm{RIHSA}}
$$

and

${ }^{\mathrm{R}} \mathrm{RIHSA}$ and ${ }^{\mathrm{R}} \mathrm{Rb}$ : net number of counts collected on the scaler from 30 to 90 seconds after the injection of RIHSA and $\mathrm{Rb}$, respectively; $\overline{\mathrm{a}} \mathrm{RIHSA}$ and $\overline{\mathrm{a}} \mathrm{Rb}$ : radioactive concentrations per millilitre of arterial blood sampled from 30 to 90 seconds after the injection of RIHSA and rubidium, respectively; $\overline{\mathrm{n}}$ : the relative counting efficiency defined in equation (I).

(2) Calculation of MCR from the praecordial trace (Fig.):

$$
M C R=\frac{D_{f} \cdot F \cdot 60 \cdot 100}{\int_{0}^{\infty}{ }^{R} R b(t) d t}
$$

where $D_{\mathrm{f}}=$ average net deflection $(\mathrm{mm})$ of the ratemeter trace from 30 to 90 seconds.

\section{Subjects}

Eight patients were studied. They all had sustained a recent myocardial infarction, diagnosed on clinical, laboratory, and electrocardiographic data. The study

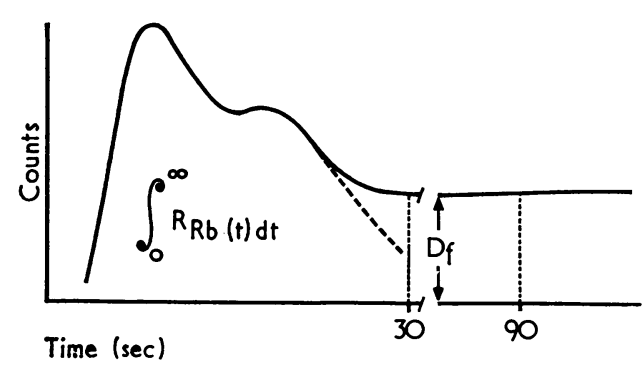

FIG. Calculation of myocardial clearance of rubidium from the praecordial tracing (see text). The area under the radiocardiographic curve is calculated after semilogarithmic extrapolation of the final downslope. $D_{f}$, the average deflection above background from 30 to 90 seconds after injection. (Reproduced from Gould et al., I972). was performed an average of Io days after the acute myocardial infarction. The clinical information on the entire group is listed in the Table.

The procedure was explained in detail to the subjects and the investigative nature of the study was stressed. An informed consent was then obtained from all the subjects.

\section{Results}

Complete data on the 8 patients are presented in the Table. The average value of the myocardial fraction of the praecordial counting rate $(F)$ in the subjects studied with ${ }^{86} \mathrm{Rb}$ was $69.5 \pm 8.1$ per cent. The myocardial clearance of rubidium averaged $89.3 \pm$ $29.9 \mathrm{ml} / \mathrm{min}$ per $100 \mathrm{~g}$ of myocardium.

\section{Effect of phentolamine}

In all of the 8 cases, the myocardial clearance increased after phentolamine. The rise ranged from II.0 to $60.0 \mathrm{ml} / \mathrm{min}$ per $100 \mathrm{~g}$ myocardium. The average change in the group amounted to $28 \mathrm{ml} / \mathrm{min}$ per $100 \mathrm{~g}$, which was statistically significant $(\mathbf{P}<$ 0.01 ). Phentolamine produced a small but significant fall in the diastolic blood pressure and a significant increase in the cardiac rate.

Two isotopes are required in this method. The praecordial counting rate of the nondiffusible indicator RIHSA is related to the radioactive concentration in blood. On the other hand, after the intravenous injection of ${ }^{86} \mathrm{Rb}$ the praecordial activity is made up of an intravascular and an extravascular component. The latter is mainly caused by myocardial activity. Subtraction of the intraventricular activity from the intravascular and myocardial activity will give only the myocardial activity.

\section{Discussion}

Donato et al. (1966), in their recent publication, have described the measurement of coronary blood flow by external counting using radioactive rubidium. However, the absolute flow cannot be determined with this method since individual variability in depth and size of the heart prevents an absolute estimate of myocardial uptake of the radioisotope. The obtained value for myocardial clearance of rubidium represents the mean flow per unit mass, and it is conveniently expressed per $100 \mathrm{~g}$ myocardium.

A major advantage of this technique is the avoidance of coronary sinus catheterization which enhances the practical value of this method. Further, the entire measurement may be completed in 90 seconds, which is an obvious advantage compared to the indirect Fick technique which uses $\mathrm{N}_{2} \mathrm{O}$, inert 
TABLE Results in acute myocardial infarction group

\begin{tabular}{|c|c|c|c|c|c|}
\hline Patient's age, sex, and condition & $\begin{array}{l}\text { Experimental } \\
\text { state }\end{array}$ & $F \%$ & $\begin{array}{l}\text { Myocardial } \\
\text { clearance of } R b \\
(\mathrm{ml} / \mathrm{min} \text { per } 100 \mathrm{~g})\end{array}$ & $\begin{array}{l}\text { Blood } \\
\text { pressure } \\
(k P a)\end{array}$ & $\begin{array}{l}\text { Heart } \\
\text { rate } \\
\text { (beats/min) }\end{array}$ \\
\hline $\begin{array}{l}64, M \text {, inferior wall myocardial infarction ( } 8 \text { days } \\
\text { old) }\end{array}$ & $\begin{array}{l}\text { Control } \\
\text { Phentolamine }\end{array}$ & $\begin{array}{l}56.6 \\
67.9\end{array}$ & $\begin{array}{l}63.3 \\
92.5\end{array}$ & $\begin{array}{l}16.6 / 10.6 \\
16.0 / 10.0\end{array}$ & $\begin{array}{l}78 \\
80\end{array}$ \\
\hline $5 \mathrm{I}, \mathrm{F}$, inferior wall myocardial infarction ( 19 days & Control & 72 & II 4 & $21.3 / 13.8$ & 100 \\
\hline old) & Phentolamine & 78 & 174 & $20.2 / 13.6$ & 100 \\
\hline $6 \mathrm{I}, \mathrm{M}$, inferior wall myocardial infarction ( 8 days & Control & 6I & 57.8 & $16.0 / 10.6$ & 100 \\
\hline old) & Phentolamine & 69 & 71.7 & $15.3 / 10.0$ & 100 \\
\hline $48, M$, anterior wall myocardial infarction ( 9 days & Control & 70 & 100 & $19.7 / 13.3$ & 100 \\
\hline $\begin{array}{l}\text { old) } \\
69, M \text {, inferior wall myocardial infarction ( } 6 \text { days }\end{array}$ & Phentolamine & $7 \mathbf{I}$ & 125 & $17.3 / 12.5$ & 108 \\
\hline $69, M$, inferior wall myocardial infarction (6 days & Control & 62 & 83 & $15.3 / 10.6$ & 88 \\
\hline old) & Phentolamine & 74 & 113 & $14.6 / 9.3$ & 100 \\
\hline $\begin{array}{l}57, F \text {, inferior wall myocardial infarction ( } 8 \text { days } \\
\text { old) }\end{array}$ & Control & 79 & 68 & $16.0 / 10.6$ & 80 \\
\hline $\begin{array}{l}54, F \text {, inferior wall myocardial infarction (8 days } \\
\text { old) }\end{array}$ & $\begin{array}{l}\text { Phentolamine } \\
\text { Control } \\
\text { Phentolamine }\end{array}$ & $\begin{array}{l}75 \\
78 \\
88\end{array}$ & $\begin{array}{r}97 \\
153 \\
164\end{array}$ & $\begin{array}{l}14.6 / 10.6 \\
17 \cdot 3 / 13.3 \\
20.0 / 12.0\end{array}$ & $\begin{array}{r}84 \\
90 \\
9\end{array}$ \\
\hline $\begin{array}{l}41, F \text {, inferior wall myocardial infarction ( } 13 \text { days } \\
\text { old) }\end{array}$ & $\begin{array}{l}\text { Control } \\
\text { Phentolamine }\end{array}$ & $\begin{array}{l}77 \\
73\end{array}$ & $\begin{array}{r}75 \\
101\end{array}$ & $\begin{array}{l}17.8 / 12.0 \\
16.8 / 10.6\end{array}$ & $\begin{array}{r}72 \\
78\end{array}$ \\
\hline Mean $\pm S D$ & $\begin{array}{l}\text { Control } \\
\text { Phentolamine } \\
\text { P value }\end{array}$ & $\begin{array}{l}69.5 \pm 8.1 \\
74.5 \pm 6.0 \\
\mathrm{NS}\end{array}$ & $\begin{array}{l}89.3 \pm 29.9 \\
117.3 \pm 33.3 \\
<0.01\end{array}$ & $\begin{array}{l}17.5 / 12.0 \\
16.9 / 11.0 \\
N S<0.01\end{array}$ & $\begin{array}{l}88.5 \\
93.8 \\
<0.02\end{array}$ \\
\hline
\end{tabular}

Conversion from SI Units to Traditional Units: I $\mathrm{kPa} \approx 7.5 \mathrm{mmHg}$.

radioactive gases or ${ }^{131}$ I antipyrine. Donato has stressed that a unique feature of this technique is that it measures the average flow to the entire myocardial mass, independent of the venous drainage. Unperfused areas which do not contribute to the indirect Fick values, since they do not extract the indicator, contribute to the clearance values by the ${ }^{86} \mathrm{Rb}$ method, in which the indicator content of the entire heart is averaged. Therefore, areas with no indicator actually contribute with their zero value to the average.

Donato believes that the most significant advantage of the technique is that the flow value measured by the myocardial clearance of rubidium represents actual flow to true capillaries.

The main limitation of the method stems from dosimetric limitation. The small percentage of gamma radiations emitted by ${ }^{86} \mathrm{Rb}$ demands the use of relatively large radioactive doses which limit the number of measurements that may be performed in the individual patient to a maximum of two.

Coronary blood flow measured by the ${ }^{86} \mathrm{Rb}$ method is reliable and reproducible. Donato measured coronary blood flow in the same patient with the $\mathrm{N}_{2} \mathrm{O}$ saturation method as well as the ${ }^{86} \mathrm{Rb}$ external counting method. The average coronary blood flow values in the II subjects using the $\mathrm{N}_{2} \mathrm{O}$ method was $72.0 \pm 16.8(\mathrm{SD}) \mathrm{ml} / \mathrm{min}$ per $100 \mathrm{~g}$ myocardium, and in the same group using the ${ }^{86} \mathrm{Rb}$ method was $68.6 \pm$
I6.I (SD) $\mathrm{ml} / \mathrm{min}$ per $100 \mathrm{~g}$ myocardium. Further, the rubidium clearance values reported by Donato in his normal subjects and his stable coronary heart disease patients were similar to the values found in our laboratory (Gould et al., 1972).

In our present study, every patient responded to the phentolamine infusion with a significant increase in the myocardial clearance of rubidium. This was associated with a small but significant decline in the diastolic blood pressure and a significant small rise in the cardiac rate.

Kelly et al. (1973) have recently observed that phentolamine administration produced, in hypertensive patients with a recent myocardial infarction, a significant reduction in the left ventricular filling pressure and a rise in the cardiac index. This improvement in cardiac function was accomplished with only a minimal reduction in the systemic arterial pressure. Similarly, comparable haemodynamic improvement can be achieved with a phentolamine infusion in normotensive or hypotensive patients with an acute myocardial infarction (Gould et al., 1974). It had previously been demonstrated that an infusion of phentolamine is an effective treatment of congestive heart failure (Gould, Zahir, and Ettinger, I969; Majid, Sharma, and Taylor, 1971 ; Gould et al., I970a) or pulmonary oedema (Gould et al., 1970b) in patients without an acute myocardial infarction.

This improvement in cardiac function may be 
explained by the recent observations of various workers. Dairman et al. (1968) administered phentolamine $(5 \mathrm{mg} / \mathrm{kg})$ to rats. At the height of alpha-receptor blockade, the conversion of a tracer dose of tyrosine ${ }^{14} \mathrm{C}$ to noradrenaline in the heart, brain, and adrenal gland was increased threefold, with no alteration in specific activity of tyrosine in blood and tissues. From these studies, Dairman concluded that receptor blockade led to increased synthesis and release of noradrenaline in the three organs that were measured. This contention has received support from the recent work of Bagwell et al. (1970). They administered $5 \mathrm{mg} / \mathrm{kg}$ of phentolamine to 7 experimental animals and observed an increase in the left ventricular contractile force. If the animals were pretreated with reserpine, the inotropic action of phentolamine could be blocked. A subsequent infusion of noradrenaline could then restore the inotropic effect. The authors concluded that the positive inotropic action of phentolamine was indirect and dependent on the release of noradrenaline.

It has been recently demonstrated that phentolamine has beta-adrenergic stimulating properties as well as alpha-adrenergic blocking effects. This beta-adrenergic stimulating action is suggested by the observation that the fall in blood pressure and the increase in cardiac rate produced by $5 \mathrm{mg}$ phentolamine can be significantly blocked by the prior administration of propranolol (Zahir and Gould, 1971). Propranolol can similarly block the inotropic and chronotropic action of phentolamine in dogs (Singh, Hood, and Abelmann, 1970). The drug also has a peripheral vasodilating effect which is not blocked by atropine (Goodman and Gilman, 1955). Taylor et al. (1965) believe that a direct relaxing effect on the vascular smooth muscle plays the dominant role in the production of the conspicuous peripheral vasodilatation. However, the recently described beta-adrenergic stimulating action of phentolamine probably also contributes to the peripheral vasodilatation.

The various factors that influence myocardial oxygen consumption have recently been delineated (Sonnenblick, Ross, and Braunwald, I968). The increased velocity of contraction, and the improvement in contractility produced by phentolamine (Gould et al., 1969) would be associated with an increase in the myocardial oxygen consumption. The minimal blood pressure and cardiac rate changes in our study would not greatly affect the oxygen requirements. The intramyocardial tension, as defined by the law of Laplace, plays a major role in the oxygen requirements of the heart. It has previously been demonstrated that the left ventricular end-diastolic volume is reduced in patients with cardiac disease after a phentolamine infusion (Gould et al., 1969). Thus, this reduction in cardiac size would lead to a diminution in the myocardial oxygen consumption requirements. It is probable that the myocardial oxygen consumption remains relatively unchanged. In support of this contention, Nagasawa et al. (1973) recently determined the myocardial oxygen consumption and the coronary blood flow in II dogs with an experimentally induced myocardial infarction. These parameters were measured before and 20 minutes after an infusion of phentolamine at $2 \mathrm{mg} / \mathrm{kg}$ per min. They observed that the myocardial oxygen consumption remained relatively unchanged while the coronary blood flow to ischaemic areas increased.

It appears that phentolamine is a good agent for the treatment of left ventricular dysfunction associated with an acute myocardial infarction. It can increase coronary blood flow to the heart while it probably has little effect on overall myocardial oxygen requirements. Phentolamine produces a fall in the left ventricular end-diastolic pressure and a rise in the cardiac output (Kelly et al., 1973; Gould et al., 1974). Further, the drug is a potent antiarrhythmic agent (Weinstein et al., 1973). It now seems advisable to widen the clinical experience with this drug.

\section{References}

Bagwell, E. E., Hilliard, C. C., Daniell, H. B., Taylor, P. L., and Walton, R. P. (1970). Studies on the inotropic mechanism of phentolamine (abstract). American fournal of Cardiology, 25, 83.

Dairman, W., Gordon, R., Spector, S., Sjoerdsma, A., and Udenfriend, S. (1968). Effect of $\alpha$-blockers on catecholamine biosynthesis. Federation Proceedings, 27, 240.

Donato, L., Bartolmei, G., Federighi, G., and Torreggiano, G. (1966). Measurement of coronary blood flow by external counting with radioactive rubidium. Critical appraisal and validation of the method. Circulation, 33, 708.

Fortuin, N. J., Kaihara, S., Becker, L. C., and Pitt, B. (I97I). Regional myocardial blood flow in the dog studied with radioactive microspheres. Cardiovascular Research, 5, 33I.

Goodman, L. S., and Gilman, A. (1955). The Pharmacological Basis of Therapeutics, and ed., p. 584. Macmillan, New York.

Gould, L., Collica, C., Zahir, M., and Gomprecht, R. F. (1972). Ethyl alcohol. Effects on coronary blood flow in man. British Heart Fournal, 34, 815.

Gould, L., Reddy, C. V. R., Kalanithi, P., Espina, L., and Gomprecht, R. F. (1974). Use of phentolamine in acute myocardial infarction. American Heart fournal, 88, 144 .

Gould, L., Zahir, M., and Ettinger, S. (I969). Phentolamine and cardiovascular performance. British Heart fournal, 31, 154 .

Gould, L., Zahir, M., Shariff, M., and Giuliani, M. (I970a). Phentolamine - use in congestive heart failure. Fapanese Heart fournal, Ir, 7.

Gould, L., Zahir, M., Shariff, M., and Giuliani, M. (1970b). Phentolamine: use in pulmonary edema. fapanese Heart fournal, II, I4I. 
Kelly, D. T., Delgado, C. E., Taylor, D. R., Pitt, B., and Ross, R. S. (1973). Use of phentolamine in acute myocardial infarction associated with hypertension and left ventricular failure. Circulation, 47, 729 .

Majid, P. A., Sharma, B., and Taylor, S. H. (1971). Phentolamine for vasodilator treatment of severe heart-failure. Lancet, 2, 719.

Maroko, P. R., Kjekshus, J. K., Sobel, B. E., Watanabe, T., Covell, J. W., Ross, J., and Braunwald, E. (1971). Factors influencing infarct size following experimental coronary artery occlusions. Circulation, 43, 67.

Nagasawa, K., Vyden, J. K., Forrester, J., and Corday, E. (1973). Effect of phentolamine on cardiac performance and energetics in acute infarction (abstract). Circulation, 48, Suppl. 4, 199.

Singh, J. B., Hood, W. B., and Abelmann, W. H. (1970). Beta adrenergic mediated inotropic and chronotropic actions of phentolamine (abstract). American fournal of Cardiology, 26, 660 .
Sonnenblick, E. H., Ross, J., Jr., and Braunwald, E. (1968). Oxygen consumption of the heart. New concepts of its multifactoral determination. American fournal of Cardiology, 22, 328.

Taylor, S. H., Sutherland, G. R., MacKenzie, G. J., Staunton, H. P., and Donald, K. W. (1965). The circulatory effects of intravenous phentolamine in man. Circulation, 31, 74I.

Weinstein, T., Gould, L., Reddy, C. V. R., and Gomprecht, R. F. (1973). Phentolamine for prophylaxis of arrhythmias in acute myocardial infarction (abstract). Circulation, 48, Suppl. 4, 229.

Zahir, M., and Gould, L. (1971). Phentolamine and betaadrenergic receptors. Fournal of Clinical Pharmacology, II, 197.

Requests for reprints to Dr. Lawrence Gould, Cardiac Catheterization Laboratory, Misericordia Hospital, 600 East 233rd Street, Bronx, N.Y. I0466, U.S.A. 